\title{
PROGRAM EDUKASI ASTRONOMI MELALUI KEGIATAN STREAM UNTUK SISWA SEKOLAH DASAR DALAM UPAYA PENINGKATAN KESADARAN KEAMANAN PENGAMATAN PERISTIWA GERHANA MATAHARI
}

\author{
Dede Trie Kurniawan ${ }^{1)}$, Dina Pratiwi Dwi Santi ${ }^{2)}$, Sri Maryanti ${ }^{3)}$ \\ ${ }^{1)}$ PGSD FKIP Universitas Swadaya Gunung Jati Cirebon dhe3kurniawan@ gmail.com \\ ${ }^{2)}$ PGSD FKIP Universitas Swadaya Gunung Jati Cirebon dinapratiwids@ @kip-unswagati.ac.id \\ ${ }^{3}$ Pendidikan Biologi FTK UIN Sunan Gunung Djati Bandung sri.maryanti@uinsgd.ac.id
}

\begin{abstract}
Abstrak
Pengabdian ini bertujuan untuk mengimplementasikan pembelajaran berbasis STREAM (Sains, Teknologi, Religi, Teknik, Seni dan Matematika) dengan konteks materi gerhana matahari cincin untuk siswa sekolah dasar. Kegiatan edukasi astronomi ini sebagai upaya peningkatan kesadaran keamanan pengamatan dalam mengamati peristiwa gerhana matahari cincin bagi siswa sekolah dasar dengan melalui pendekatan pembelajaran STREAM. Kegiatan ini dimaksudkan sebagai wahana edukasi astronomi dalam menanamkan sebuah pemahaman kesadaran keamanan kepada siswa SD dalam mengamati peristiwa gerhana matahari disalah satu sekolah dasar kota Cirebon dan Bandung. Melalui kegiatan ini diharpkan guru - guru dan siswa dapat lebih eksplorasi kreatfitas pengajaranya, menyenangi, siap berpartsipasi dalam pendidikan astronomi bagi anak sedari dini di pembelajaran IPA menjadi menyenangkan dalam memahami konten fisika mengenai astronomi. Menjelang akhir tahun nanti, tepatnya pada tanggal 26 Desember 2019, masyarakat Indonesia akan mendapat kesempatan untuk menyaksikan sebuah peristiwa astronomi yang langka dan spektakuler, yaitu Gerhana Matahari Cincin. Pengabdian ini diadakan pada bulan November - Desember 2019 di salah satu sekolah dasar kabupaten Bandung dan kota Cirebon. Kegiatan ini dilakukan melalui beberapa tahap termasuk mengenai Implementasi STREAM kepada guru kelas seperti paparan STREAM, penjelasan tentang merancang pembelajaran berbasis STREAM dan Impelementasi Hasil Rancangan pembelajaran berbasis STREAM di kelas yang telah di sepakati untuk dijalankan program. Kuesioner guru dan siswa diberikan untuk mengumpulkan data tentang respon atas pembelajaran STREAM yang di impelemntasikan. Kata Kunci: Pembelajaran, STREAM, Tematik, Sekolah Dasar, IPA
\end{abstract}

\begin{abstract}
This service aims to implement STREAM-based learning (Science, Technology, Religion, Engineering, Art and Mathematics) with the context of ring solar eclipse material for elementary school students. This astronomy education activity is an effort to increase awareness of observation security in observing ring solar eclipse events for elementary school students through the STREAM learning approach. This activity is intended as a vehicle for astronomical education in instilling an understanding of security awareness to elementary students in observing solar eclipse events in one of the elementary schools of the cities of Cirebon and Bandung. Through this activity teachers and students are expected to be more able to explore the creativeness of their instructors, enjoy, be prepared to participate in astronomy education for children from an early age in learning science to be fun in understanding the physics content about astronomy. Towards the end of the year, precisely on December 26, 2019, the people of Indonesia will have the opportunity to witness a rare and spectacular astronomical event, the Ring Solar Eclipse. This service is held in November - December 2019 in one of the elementary schools in Bandung regency and Cirebon city. This activity is carried out through several stages including the Implementation of STREAM to classroom teachers such as STREAM exposure, explanation of designing STREAM-based learning and Implementation of STREAMbased learning designs in classes that have been agreed to run the program. Teacher and student questionnaires were given to collect data on responses to STREAM learning that was implemented.
\end{abstract}

Keywords: Learning, STREAM, Thematic, Elementary School, Natural Sciences

\section{PENDAHULUAN}

Menjelang akhir tahun nanti, tepatnya pada tanggal 26 Desember 2019, masyarakat Indonesia akan mendapat kesempatan untuk menyaksikan sebuah peristiwa astronomi yang langka dan spektakuler, yaitu Gerhana Matahari Cincin. Gerhana ini dapat dilihat dari sebagian wilayah timur Afrika, hampir seluruh Asia termasuk seluruh Indonesia, sebagian Rusia, dan sebagian Australia. Sementara di Indonesia, jalur pusat gerhana ini akan melintasi sebagian wilayah Sumatra dan Kalimantan. Gerhana Matahari adalah sebuah peristiwa yang terjadi jika Matahari, Bulan, dan Bumi terletak segaris dan sebidang. Akibat konfigurasi posisi seperti itu, Bulan akan menutupi piringan Matahari dan terjadilah gerhana Matahari. Berdasarkan beberapa faktor seperti jarak Bumi - Bulan, jarak Bumi - Matahari, 
serta posisi Matahari dan Bulan di langit, terdapat 3 macam gerhana Matahari yang dapat kita amati yaitu gerhana Matahari total (GMT), gerhana Matahari cincin (GMC), dan gerhana Matahari sebagian (GMS). Tambahan satu lagi berupa gerhana hibrid, yaitu ketika dalam sehari itu di sebagian waktunya terjadi gerhana total dan sebagian lainnya terjadi gerhana cincin.

Sebagai sebuah objek langit yang sangat terang, Matahari tidaklah boleh diamati dengan sembarangan, baik secara langsung dengan mata telanjang dan terlebih lagi dengan menggunakan alat bantu seperti binokuler, teleskop, dan alat optik lainnya. Energi yang dipancarkan Matahari sangatlah kuat dan tidak hanya pada cahaya tampak saja, tapi juga di cahaya ultraungu dan inframerah. Kesalahan dalam mengamati Matahari akan berakibat kerusakan pada mata (kebutaan) permanen. Prinsip utama untuk mengamati Matahari, baik dalam keadaan gerhana atau tidak, adalah dengan mengurangi cahaya yang masuk ke mata kita.

Dari Penjelasan ini maka di pandang perlu upaya untuk menimgkatkan kesadaran dan keamanan dalam pengamatan fenomena gerhana matahari untuk siswa sekolah dasar. Dewasa ini kegiatan belajar mengajar guru di sekolah dasar telah mengalami banyak perubahan. Guru mulai mengadakan inovasi dalam mengajar. Termasuk penggunaan metode pembelajaran di kelas. Tetapi metode pembelajaran yang digunakan terkadang kurang sesuai dengan materi yang diajarkan, sehingga usaha yang dilakukan pendidik dalam pengembangan dan ketrampilan ilmu akan kurang bermakna bagi peserta didik, Oleh karena itu seorang guru harus terampil dalam memilih metode yang sesuai dengan materi dan tujuan pembelajaran. Untuk pembelajaran Ilmu Pengetahuan Alam (IPA), bukan hanya untuk memahami pengetahuan tentang fakta-fakta, konsep-konsep dan pengertian IPA melainkan untuk mengembangkan keterampilan menggunakan metode ilmiah dan bersikap ilmiah untuk memecahkan masalah-masalah yang dihadapinya dalam kehidupan sehari-hari. Pendidikan IPA di arahkan untuk inkuiri (untuk mengembangkan kemampuan berfikir, bekerja dan bersikap ilmiah serta mengkomunikasikannya sebagai aspek kecakapan hidup) dan berbuat sehingga dapat membantu peserta didik untuk memperoleh pemahaman yang lebih mendalam tentang alam
sekitar.Tujuan pembelajaran IPA di SD adalah untuk menumbuhkan kemampuan berpikir siswa, bekerja dan bersikap ilmiah serta memperoleh pengetahuan, konsep dan keterampilan IPA sebagai dasar-dasar untuk melanjutkan pendidikan ke jenjang yang lebih tinggi.Tujuan tersebut dapat tercapai bila pembelajaran IPA menekankan pada proses pembelajaran IPA, melalui pembelajaran yang menekankan pada proses, maka siswa mempunyai pengalaman langsung dari berinteraksi dengan lingkungan.

Salah satu pendekatan pembelajaran yang dapat digunakan untuk melatih keterampilan berpikir kreatif adalah pendekatan pembelajaran STREAM. Pendidikan STREAM memberikan peluang kepada guru untuk memperlihatkan kepada peserta didik betapa konsep, prinsip, dan teknik dari sains, teknologi, religi, enjiniring, Art dan matematika digunakan secara terintegrasi dalam pengembangan produk, proses, dan sistem yang digunakan dalam kehidupan sehari-hari mereka.

Trends pembelajaran saat ini perlu mengikuti perkembangan abad 21 yang salah satunya dengan mengintegrasikan Science, Technology,Religi, Engineering, Art dan Mathematics (STREAM). Beberapa manfaat dari pendekatan STREAM membuat siswa mampu memecahkan masalah menjadi lebih baik, inovator, inventors, mandiri, pemikir logis, dan literasi teknologi (Morrison, 2006). Pembelajaran STEM perlu menekankan beberapa aspek dalam proses pembelajaran (NRC, 2011, pp.3$5)$.

Dari latar belakang yang telah dipaparkan, maka perlu dilakukan kegiatan edukasi astronomi sebagai upaya peningkatan kesadaran keamanan pengamatan dalam mengamati peristiwa gerhana matahari cincin bagi siswa sekolah dasar dengan melalui pendekatan pembelajaran STREAM. Kegiatan ini dimaksudkan sebagai wahana edukasi astronomi dalam menanamkan sebuah pemahaman kesadaran keamanan kepada siswa SD dalam mengamati peristiwa gerhana matahari disalah satu sekolah dasar Kota Cirebon dan bandung. Melalui kegiatan ini diharpkan guru - guru dan siswa dapat lebih eksplorasi kreatfitas pengajaranya, menyenangi, siap berpartsipasi dalam pendidikan astronomi bagi anak sedari dini di pembelajaran IPA menjadi 
menyenangkan dalam memahami konten fisika mengenai astronomi.

Tujuan umum kegiatan pengabdian edukasi astronomi sebagai upaya peningkatan kesadaran keamanan pengamatan dalam mengamati peristiwa gerhana matahari cincin melalui pendekatan pembelajaran STREAM. Selain itu tujuan kegiatan ini memberikan pengetahuan dan pemahaman atas kesadaran keamanan pengamatan dalam mengamati peristiwa gerhana matahari cincin. Melalui kegiatan program pengabdian edukasi ini diharapkan dapat menjadi wadah pengamalan ilmu dan pembelajaran dari bidang kepakaran dosen yang dimiliki. Dan melalui kegiatan program pengabdian edukasi ini dapat menjadi sebuah stimulan awal untuk membuat kelompok kepeminatan astronomi sebagai wahana ekstrakurikuler di sekolah dasar yang menjadi objek pengabdian.

\section{METODOLOGI PENGABDIAN}

\section{Solusi yang ditawarkan}

Kegiatan program pengabdian edukasi astronomi sebagai upaya peningkatan kesadaran keamanan pengamatan dalam mengamati peristiwa gerhana matahari cincin bagi siswa sekolah dasar dengan melalui pendekatan pembelajaran STREAM bisa menjadi sarana perluasan pengetahuan dan pemberian pemahaman bagi siswa mengenai dunia astronomi di Indonesia. Adapun rencana kegiatan yang dilakukan digambarkan pada Tabel 1. :

Tabel 1. Rencana Kegiatan Program Pengabdian

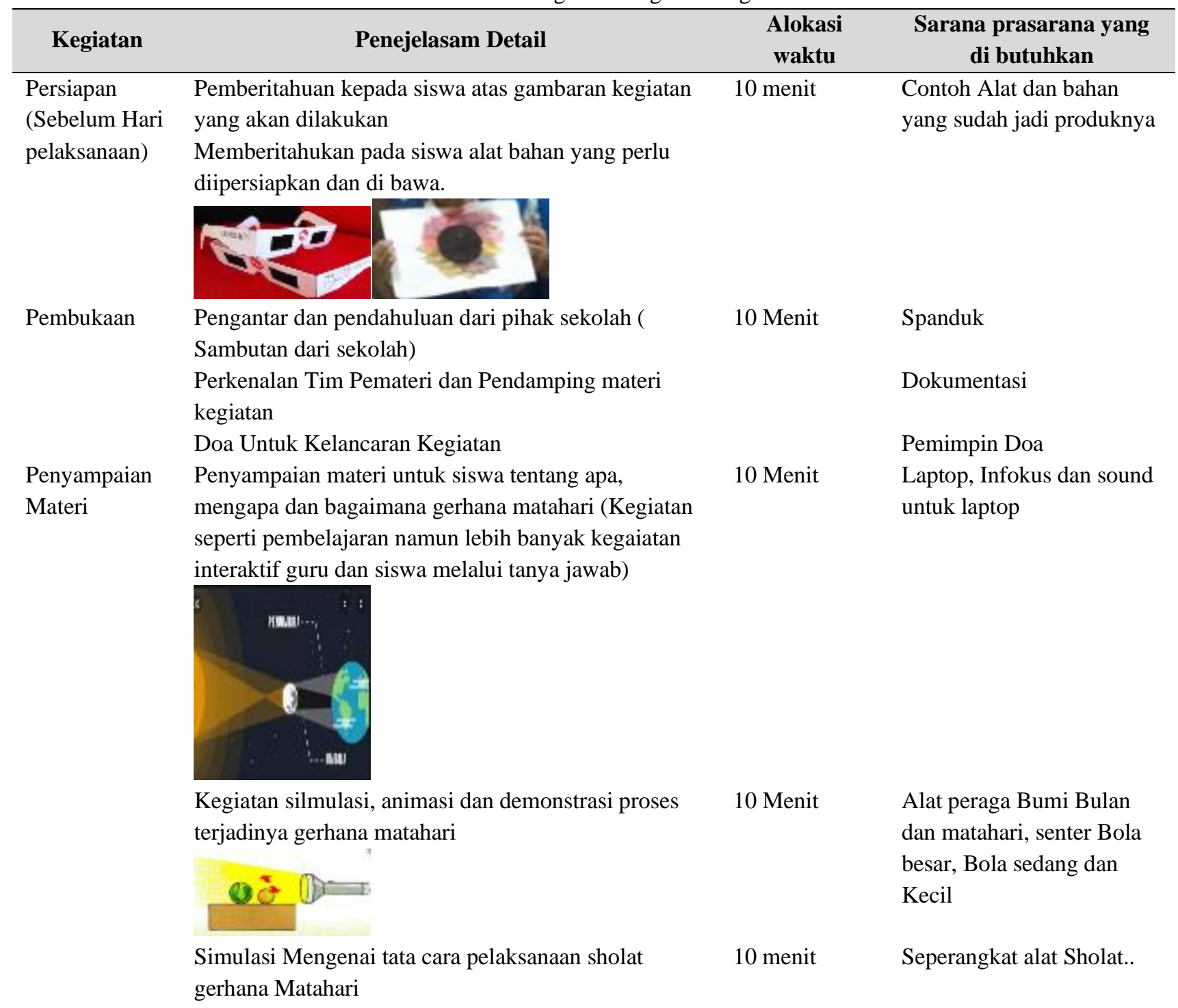




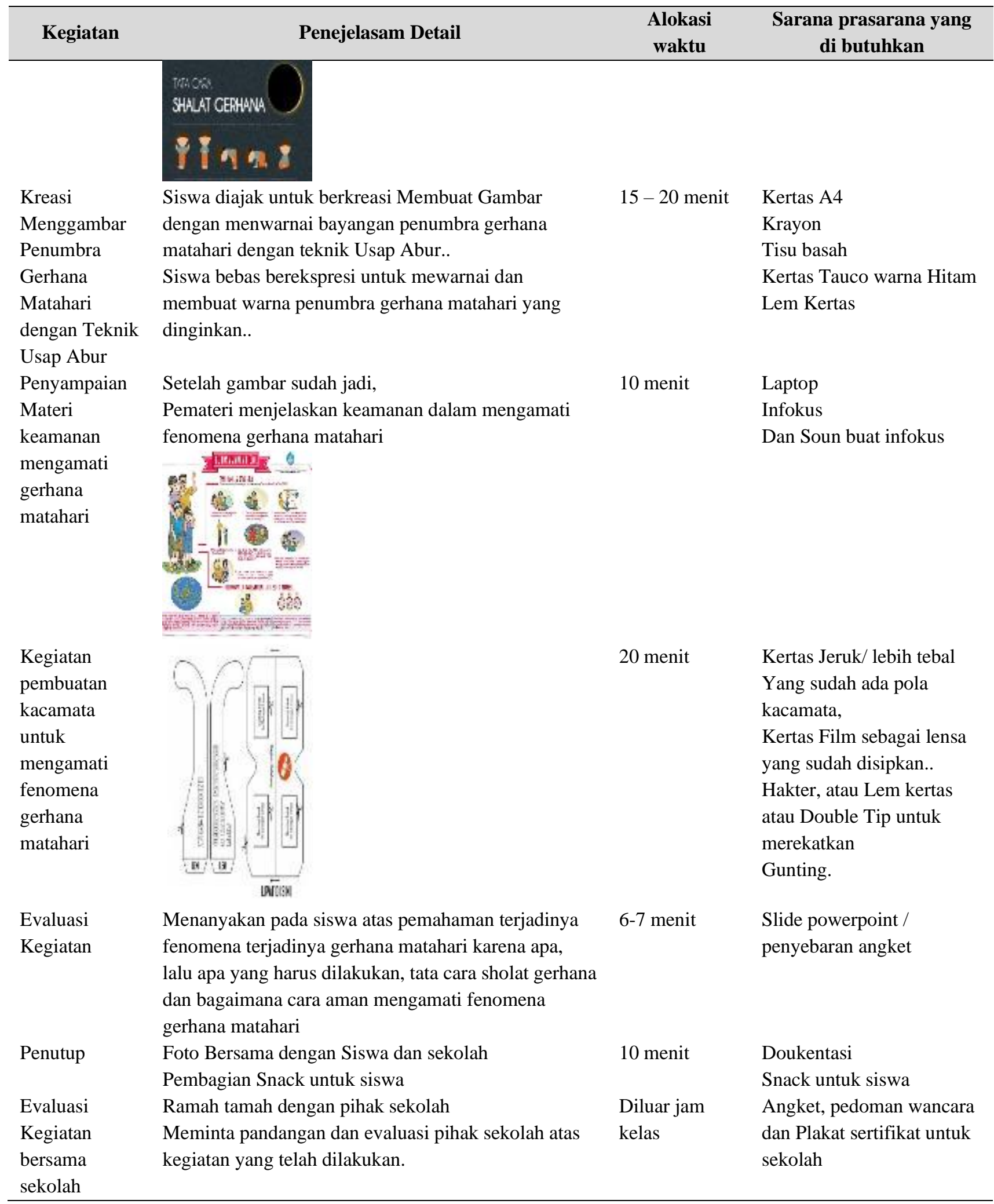

\section{Target Luaran}

Berdasarkan rencana kegiatan yang telah disusun maka target luaran yang diharapkan setelah pelaksanaan program pelatihan ini adalah siswa-siswa SD kelas rendah dan anak usia dini mendapatkan wawasan pengetahuan dan pemberian pemahaman bagi siswa mengenai wawasan dan pengetahuan untuk meingkatakan kesadaran keamanan pengamatan dalam mengamati peristiwa gerhana matahari cincin bagi siswa sekolah dasar dengan melalui pendekatan pembelajaran STREAM. 
Tabel 2. Target dan Luaran

\begin{tabular}{|c|c|}
\hline Kegiatan & Target Luaran \\
\hline $\begin{array}{l}\text { Progam edukasi } \\
\text { astronomi sebagai } \\
\text { upaya peningkatan } \\
\text { kesadaran keamanan } \\
\text { pengamatan dalam } \\
\text { mengamati peristiwa } \\
\text { gerhana matahari } \\
\text { cincin bagi siswa } \\
\text { sekolah dasar dengan } \\
\text { melalui pendekatan } \\
\text { pembelajaran } \\
\text { STREAM di salah } \\
\text { satu sekolah dasar } \\
\text { kota Cirebon dan } \\
\text { kabupaten Bandung. }\end{array}$ & $\begin{array}{l}80 \% \text { dari Siswa mampu } \\
\text { memahami tentang : } \\
\text { Peristiwa Gerhana Matahari } \\
\text { Keamanan Pengamatan } \\
\text { Gerhana Matahari } \\
\text { Hikmah dan Manfaat Sholat } \\
\text { Gerhana matahari }\end{array}$ \\
\hline $\begin{array}{l}\text { Pembentukan } \\
\text { Kepeminatan } \\
\text { Astronomi di Sekolah } \\
\text { Dasar }\end{array}$ & $\begin{array}{l}80 \% \text { dari peserta mampu } \\
\text { memahami dan dapat } \\
\text { menjelaskan kembali } \\
\text { mengenai materi gerhana } \\
\text { matahari cincin dan prosesdur } \\
\text { keamanan dalam mengamati } \\
\text { peristiwa gerhanan matahari } \\
\text { serta tata cara pelaksanaan } \\
\text { sholat gerhana matahari }\end{array}$ \\
\hline Luaran Wajib & $\begin{array}{l}\text { satu artikel ilmiah } \\
\text { satu artikel pada media massa } \\
\text { cetak/elektronik; } \\
\text { video kegiatan; dan } \\
\text { peningkatan keberdayaan } \\
\text { mitra sekolah yang dipilih }\end{array}$ \\
\hline
\end{tabular}

Selain itu melalui kegiatan program pengabdian edukasi ini dapat menjadi sebuah stimulan awal untuk membuat kelompok kepeminatan astronomi sebagai wahana ekstrakurikuler di sekolah dasar yang menjadi objek pengabdian. Dan Bila Sudah terbentuk kelompok keminatan ini akan dibuat program pendampingan bagi guru yang ditugaskan sebagai pembina ekstrakurikuler ini. Untuk memenuhi luaran wajib yang disyaratkan oleh Lembaga pengabdian kepada masyarakat maka akan di hasilkan dari kegiatan ini berupa satu artikel ilmiah, satu artikel pada media masa baik cetak maupun elektronik, video pelaksanaan kegiatan dan Peningkatan keberdaaayan pada mitra sekolah yang di tunjuk.

\section{Rencana Monitoring dan evaluasi}

Tujuan monitoring dan evaluasi pelaksanaan program pengabdian edukasi ini, antara lain:
- Untuk menjamin terlaksananya pelatihan sesuai dengan target dan rencana yang telah ditetapkan.

- Agar ada umpan balik terhadap pelaksanaan pelatihan.

- Untuk membantu pemangku kepentingan belajar lebih banyak Memahami pentingnya pengenalan dunia astronomi indonesia untuk siswa sekolah dasar.

- Agar penyelenggara pelatihan mampu mempertanggungjawabkan penggunaan dana.

Instrumen yang digunakan untuk mengumpulkan data untuk monitoring dan evaluasi, yaitu:

1. Kuesioner dirancang untuk mengungkap reaksi peserta terhadap pelaksanaan penyluhan.

2. Pedoman wawancara untuk Guru Pendamping dan Siswa

3. Dokumentasi berupa foto dan video pelaksanaan kegiatan edukasi astronomi untuk gerhana matahari dengan pendekatan STREAM

Tabel 3. Rencana Monitoring dan Evaluasi

\begin{tabular}{llll}
\hline $\begin{array}{l}\text { Level } \\
\text { Evaluasi }\end{array}$ & Jenis data & $\begin{array}{l}\text { Sumber } \\
\text { data }\end{array}$ & Intrumen \\
\hline Reaksi & Pemateri & Peserta & $\begin{array}{l}\text { Kuesioner } \\
\text { partisipan }\end{array}$ \\
& & & $\begin{array}{l}\text {-Pedoman } \\
\text { wawancara }\end{array}$ \\
\cline { 2 - 4 } & Pelaksanaan & Peserta & - \\
& kegiatan & & $\begin{array}{l}\text { Kuesioner } \\
\text {-Pedoman }\end{array}$ \\
& & & wawancara \\
\hline $\begin{array}{l}\text { Dukungan } \\
\text { organisasi } \\
\text { dan belajar }\end{array}$ & Guru Kelas & Guru & Kuesioner \\
$\begin{array}{llll}\text { Penggunaan } \\
\text { pengetahuan } \\
\text { dan }\end{array}$ & Siswa & Pendamping & \\
keterampilan & & Guru Kelas & lembar \\
baru & & I,II dan III & observasi \\
& & Mengenai & \\
\hline
\end{tabular}

\section{PELAKSANAAN KEGIATAN}

Telah dilaksanakan kegiatan Program Edukasi Astronomi Melalui Kegiatan Stream (Science Technology Engineering Religi Art And Mathematics) Untuk Siswa Sekolah Dasar Dalam Upaya Peningkatan Kesadaran Keamanan Pengamatan Peristiwa Gerhana Matahari Di Bulan 
Desember 2019 di RA Atta'awun Komplek Pilar Biru Kabupaten bandung. Selain Itu Kegiatan ini juga telah dilakukan di SD IT Assunnah Kota Cirebon dan Kegiatan Sesi Desiminasi serta diskusi hasil implementasi program bersama mahasiswa PGSD Universitas Negeri Jakarta (UNJ) di kegiatan Workshop Pembelajaran STREAM di PUDAK Scientific Bandung. Kegiatan ini dilaksanakan dengan acara tatap muka penyampaian materi, demonstrasi, story telling, pemutaran video, praktik sains serta ibadah, bermain mewarnai gerhana matahari dan membuat kacamata pengamatan gerhana matahari dari bahan yang telah disediakan.

Secara garis besar kegiatan berjalan dengan baik dan lacar. Pertemuan tatap muka dengan metode ceramah, story telling dan demonstrasi menggunakan video melalu media laptop dan infokus yang difasilitasi oleh sekolah. Kegiatan ini dilaksanakan sehari yaitu pada hari Rabu tanggal 27 November 2019 dari pukul 08.00 - 11.00 WIB. Peserta kegiatan berjumlah 18 orang siswa yang merupakan siswa siswi Ra Atta'awun kelas A dan B Usia 5 - 6 Tahun. Lokasi Penyelenggaraan Kegiatan Pengabdian ini dilaksanakan di RA Atta'awun Komplek pilar biru jalan pilar barat no.15 Rt.02 / Rw 12 Desa Cibiru Hilir Kecamatan cileunyi Kabupaten Bandung. Adapun materi dan fasilitator kegiatan dilakukan dan disampaikan oleh Bapak Dr. Dede Trie Kurniawan, S.Si., M.Pd selaku dosen PGSD FKIP Universitas swadaya gunung Jati Cirebon. Selain itu kegiatan ini juga dilakukan bersama siswa kelas III SD IT Assunnah Kota Cirebon degan format kegiatan yang sama. Kegiatan di SD IT Assunah Kota Cirebon dilaksanakan pada hari Jumat 11 Oktober 2019 dari pukul 07.30 - 10.30 WIB. Kegiatan di SD IT Assunah berkolaborasi dengan Ibu Dina Dwi Pratiwi Dwi Santi, M.Pd Selaku dosen PGSD FKIP Universitas Swadaya Gunung Jati Cirebon. Kegiatan program pengabdian edukasi ini bagi siswa SD kelas rendah ini telah dilaksanakan di sekolah SD IT As Sunnah Kota Cirebon. Target peserta pelatihan ini adalah 40 siswa kelas III. Program pengabdian edukasi ini juga akan dilaksanakan untuk siswa di salah satu pendidkan anak usia dini (PAUD) sekitar wilayah jawa barat. Dalam Pelaksananya kegiatan ini didampingi oleh 3 orang anggota dari mahasiswa PGSD FKIP Unswagati Cirebon.
Untuk Desiminasi dan diskusi implementasi program STREAM di pendidikan dasar dilakukan pada kegiatan workshop yang diselenggarakan oleh PUDAK Scientific bersama dosen dan mahasiswa PGSD Universitas Negeri Jakarta pada hari rabu 18 Desember 2019 di Gedung pelatihan Pudak Scientific Bandung.

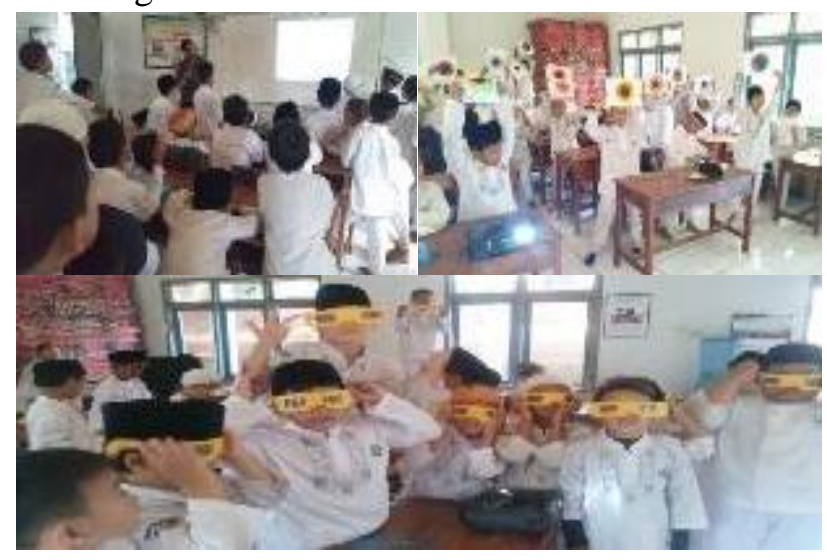

Gambar 1. Implementasi Program di SD IT Assunah Kota Cirebon

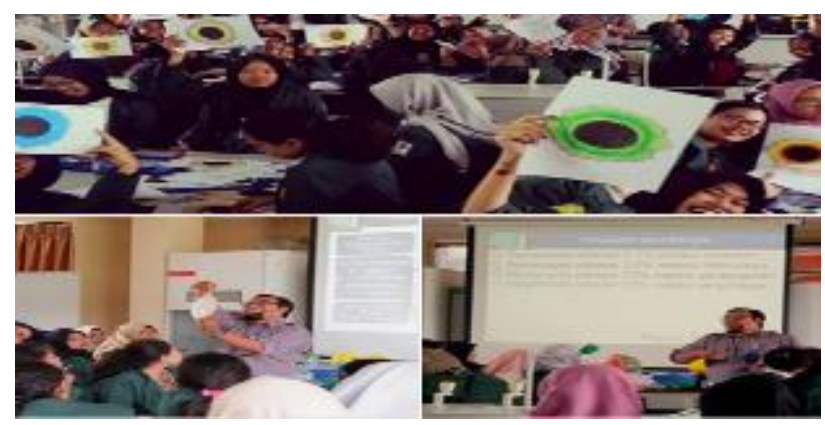

Gambar 2. Diseminasi dan Diskusi Bersamas Mahasiswa dan Dosen PGSD Universitas Negeri Jakarta di Pudak Scientifc Bandung

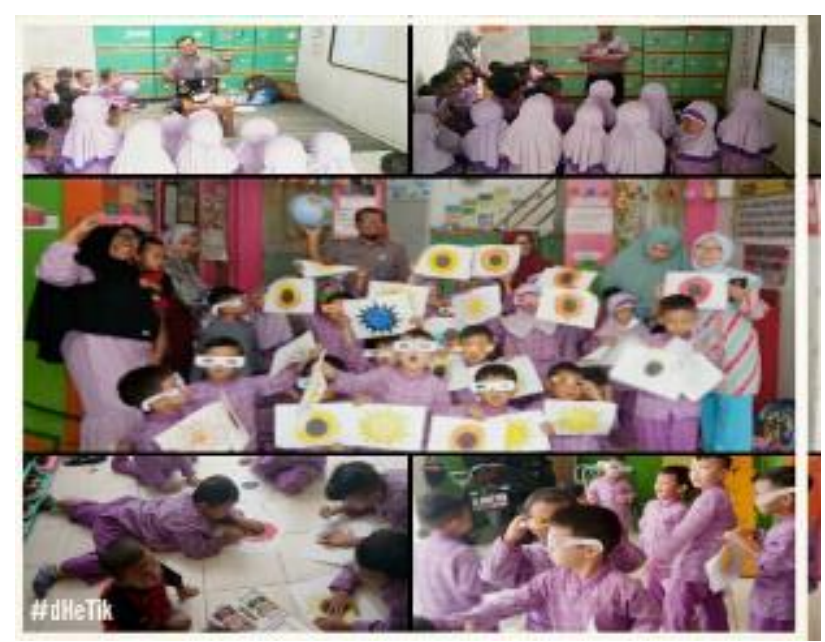

Gambar 3. Implementasi Program di RA Attaawun Kab. Bandung 


\section{HASIL DAN PEMBAHASAN}

Hasil yang didapat dari pengabdian ini adalah rancangan aktifitas pembelajaran dengan pendekatan STREAM (Sains Teknologi, Religi, Enjinering, seni dan Matematik) untuk siswa dalam mempelajari fenomena gerhana matahari melalui pendekatan pembelajaran tematik. Adapun secara lebih terperinci aktifitas setiap pendekatan akan dijelaskan sebagai berikut :

\section{Unsur Sains}

- Siswa dapat mengenal dan memahami benda benda antariksa seperti planet, satelit dan bintang.

- Siswa dapat memahami proses terjadinya gerhana matahari.

- Siswa dapat memahami konsep cahaya dan optik dalam fenomena pengamatan gerhana matahari.

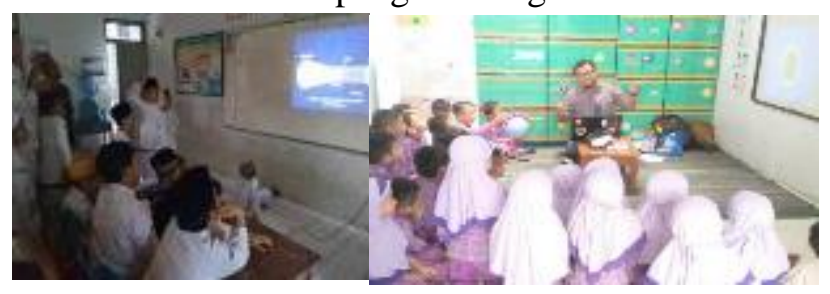

Gambar 4. Unsur Sains dalam pembelajaran STREAM

\section{Unsur Teknologi}

- Siswa dapat memahami pemanfaatan internet dalam memperoleh informasi mengenai meteorologi, geofisika dan antariksa

- Siswa dapat Mamahami Teknik Penggunaan Alat Peraga untuk Simulasi terjadinya Gerhana Matahari.

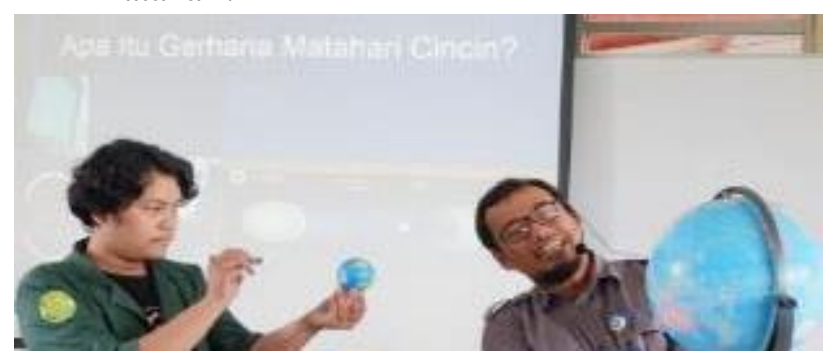

Gambar 5. Unsur Teknologi dalam pembelajaran STREAM

\section{Unsur Religi}

- Siswa dapat Memahami Bahwa Fenomena Gerhana Matahari adalah salah satu tanda kebesaran dari NYA. Hal ini dikaitkan dengan kajian Ayat yang menjelaskan fenomena gerhana Matahari.
- Ssiwa dapat melakukan dan memahami Tata Cara Pelaksanaan Sholat Gerhana Matahari

- Siswa dapat memahami apa yang perlu dilakukan saat terjadi gerhana matahari dari tinjauan keyakinan agama.

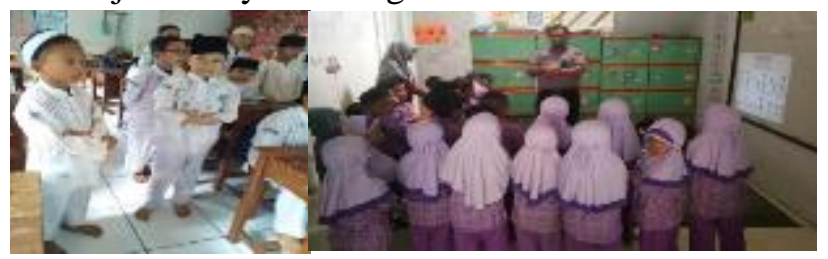

Gambar 6. Unsur Religi dalam pembelajaran STREAM

\section{Unsur Ilmu Rekayasa}

- Siswa Mampu Membuat Kacamata Pegamtaan Gerhana Matahari.

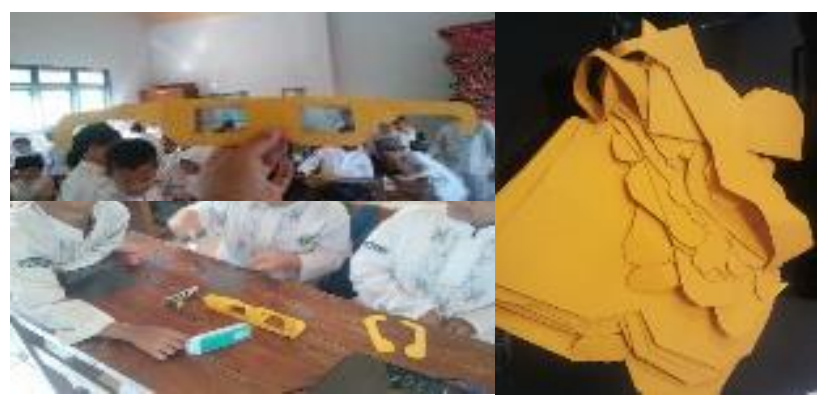

Gambar 7. Unsur Rekayasa dalam pembelajaran STREAM

\section{Unsur Seni}

- Siswa Mampu Menggnting pola kacamata pengamatan gerhana matahari

- Ssiwa Mampu Mewarnai dengan baik dan indah simulasi Bayangan Penumbra gerhanan matahari.

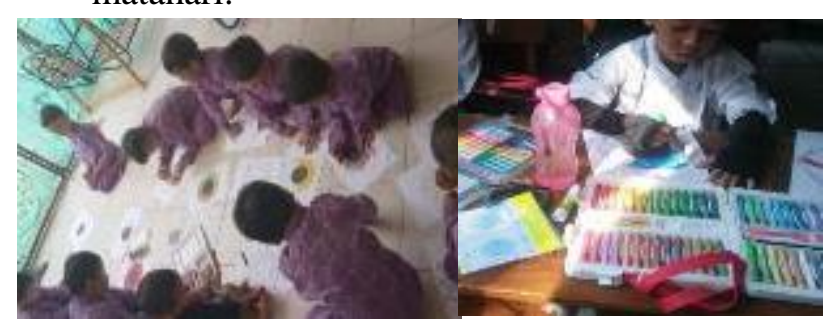

Gambar 8. Unsur Seni dalam pembelajaran STREAM

\section{Unsur Matematika}

- Siswa dapat Memahami Konsep Waktu dari Fenomena Rotasi dan revoluasi Bumi.

- Siswa dapat memahami mengapa singkatnya waktu untuk terjadinya proses gerhana matahari.

- Siswa dapat memahami konsep waktu detik, menit, jam, hari, minggu, bulan dan tahun. 


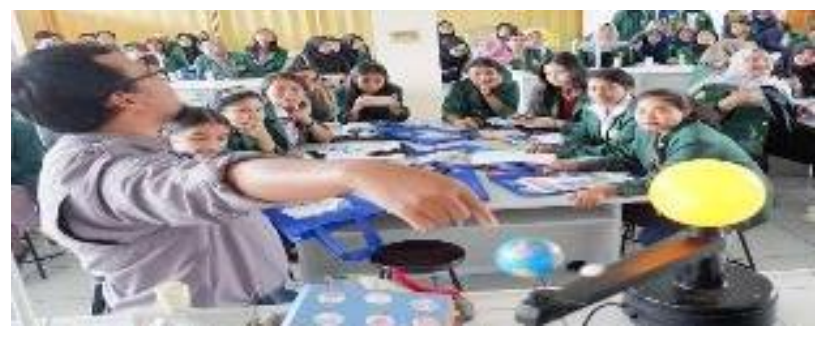

Gambar 9. Unsur Matematika dalam pembelajaran STREAM

\section{Ucapan Terima Kasih}

Penulis mengucapkan terima kasih kepada berbagai pihak yang telah membantu dalam penulisan makalah ini. Makalah ini didanai oleh Program Pengabdian Kepada Masyarakat Lembaga Pengabdian Kepada Masyarakat Universitas Swadaya Gunung Jati Tahun 2020

\section{PENUTUP}

\section{Kesimpulan}

Secara Garis besar Pelaksanaakan kegiatan Program Edukasi Astronomi Melalui Kegiatan Stream (Science Technology Engineering Religi Art And Mathematics) Untuk Siswa Sekolah Dasar Dalam Upaya Peningkatan Kesadaran Keamanan Pengamatan Peristiwa Gerhana Matahari Di Bulan Desember 2019 dapat dikategorikan sukses dan berjalan dengan baik. Hal ini dapat ditunjukan dengan sebagian besar pemberian respon dari peserta siswa RA, Siswa SD, Mahasiswa, Guru dan Kepala sekolah yang mengungkapkan bahwa kegiatan ini sangat baik karena dapat memberikan manfaat dan memperluas wawasan mereka mengenai integrasi pembelajaran yang mengkaitkan unsur sains, teknologi, religi, enjinering, seni dan matematik dalam suatu kegiatan pembelajaran tematik bagi siswa.

\section{Saran}

Berdasarkan hasil dan temuan pelaksamaan kegiatan, diajukan beberapa rekomendasi sebagai berikut:

1. Meluaskan Objek Pengabdian Ke siswa Sekolah dasar dengan mencoba mengajak siswa membuat kamera lubang jarum untuk pengamatan gerhana matahari dengan aman.

2. Membimbing dan mengembangkan program ekstrakurikuler siswa mengenai kegiatan kepeminatan bidang astronomi.
3. Menggiatkan dan mengusulkan program pengembangan pembelajaran dengan pendekatan STREAM untuk tema selain gerhana matahari dalam pembelajaran sekolah dasar.

\section{DAFTAR PUSTAKA}

Sriyati, Siti. D. Rochintaniawati, A. Widodo, Widi Purwaningsih, Riandi. 2018. Upaya Mengembangkan Kemampuan Guru Kota Bandung Dan Sekitarnya Untuk Mendesain Pembelajaran Berbasis Stem (Science Technology, Engineering And Mathematics) Melalui Kegiatan Lokakarya. Prosiding Seminar Nasional Hasil PKM LPM UNPAS. ISBN 978602-0942-254

Becker, K., \& Park, K. (2011). Effects of integrative approaches among science , technology , engineering, and mathematics ( STEM) subjects on students â€TM learning : A preliminary metaanalysis. Journal of STEM Education, 12(5), 2338. https://doi.org/10.1037/a001945

National Research Council. (2014). Engineering In K-12 Education: Understanding The Status And Improving The Prospects

Agustina, Tri Wahyu. 2019. Membekalkan Kreativitas Mahasiswa Melalui Strategi Pembelajaran Berbasis Stream Menggunakan Konten Bioteknologi Tradisional. BUIEDUIN. Februari Bol.09 No.1

Agustina, T.W., Rustaman, N.Y., Riandi, \& Purwianingsih W. (2017a). The Teaching Problems in Biotechnology. A Preliminary Research Toward Teachers' of Secondary School in East Bandung. 4th International Conference on Research, Implementation and Education of Mathematics and Science Proceedings.Yogyakarta, May 15th-16th, 2017. Hlm BE 7- BE 11. Tersedia Online: http://seminar.uny.ac.id/icriems/proceedings201 7.

Kim, Y. \& Park, N. (2012). The Effect of STEAM Education on Elementary School Student's Creativity Improvement. CCIS 339: 115-121. DOI: 10.1007/978-3-642-35264-5_16.

Wiramihardja, Suhardja $\quad$ D. 2010 Astronomi Indonesia Menapak ke Depan dan Kontribusinya pada Sebuah World Class University", dalam Pidato Ilmiah Guru Besar ITB pada 22 Mei 2010 . 
"Menikmati Gerhana Matahari Cincin" , https://nasional.kompas.com/read/2009/01/23/1 1392225/menikmati.gerhana.matahari.cincin?pag $\mathrm{e}=$ all.

Pedoman Penyusunan Proposal dan Laporan Pengabdian Dosen. Lembaga pengabdian masyarakat (LPM) Universitas swadaya gunung jati cirebon 2019

Ekspidisi gerhana matahari cincin 26 desember 2019. http://thebiggestsundial.com/news/ekspedisigerhana-matahari-cincin-26-desember-2019 